\title{
Adjuvant therapies to improve the results of pharmacological therapies in rosacea
}

\author{
Terapii adjuvante pentru îmbunătăţirea rezultatelor terapiilor farmacologice în \\ rozacee
}

\author{
Ana Maria Alexandra Stănescu', Ioana Veronica Grăjdeanu', \\ Constantin Ştefani ${ }^{1}$, Adela Mihaela Iancu ${ }^{1}$, Cristina Olariu ${ }^{1,4}$, Cristian Paparău ${ }^{2}$, \\ Camelia Cristina Diaconu ${ }^{1,3}$ \\ ${ }^{1}$ Universitatea de Medicină şi Farmacie „Carol Davila“, Bucureşti, România \\ ${ }^{2}$ Medicină Legală SJML Dâmboviţa, România \\ ${ }^{3}$ Spitalul Clinic de Urgenţă Floreasca, Bucureşti, România \\ ${ }^{4}$ Institutul Naţional de Boli Infecţioase „Prof. Dr. Matei Balş“, Bucureşti, România
}

\begin{abstract}
Rosacea is a chronic inflammatory disease of the skin. Exact pathogenesis is not yet elucidated, although all of these are influences due to the imbalance of the innate immune system, the overgrowth of skin coma and the aberrant neurovascular signaling. Rosacea has a physically limited effect, but from a psychological point of view, the impact is very high. Non-pharmacological treatments are very important in preventing triggering and subsequent care by hydration and appropriate sunscreen. From a pharmacological point of view, both systemic and topical interventions can be performed, however current therapies are not curative. Proper skin care plays a pivotal role in maintaining remission and alleviating the symptoms of rosacea.
\end{abstract}

Keywords: skin, inflammatory disease, rosacea, complementary therapies

\section{REZUMAT}

Rozaceea este o afecţiune cronică inflamatorie a pielii. Patogeneza exactă nu este încă elucidată; cu toate acestea, există influenţe din cauza dereglării sistemului imunitar înnăscut, supraaglomerarea organelor cutanate comenice şi semnalizarea neurovasculară aberantă. Rozaceea are un efect limitat din punct de vedere fizic, însă, din punct de vedere psihologic, impactul este foarte mare. Sunt foarte importante tratamentele non-farmacologice în ceea ce priveşte prevenirea declanşării şi îngrijirea ulterioară prin hidratare şi protecţie solară corespunzătoare. Din punct de vedere farmacologic, se poate interveni atât topic, cât şi sistemic; cu toate acestea, terapiile actuale nu sunt curative. Îngrijirea adecvată a pielii joacă un rol esenţial în menţinerea remisiunii şi atenuarea simptomelor rozaceei.

Cuvinte cheie: piele, afecţiune inflamatorie, rozacee, terapii complementare

\section{INTRODUCERE}

Rozaceea este o dermatoză inflamatorie comună, caracterizată prin eritem facial, telangiectazie, papule, pustule şi edeme dispuse mai ales în partea centrală a feței. Rozaceea este o entitate foarte heterogenă, cu o epidemiologie şi o patofiziologie necunoscută; modificările vasculare, în special înroşirea feței, reprezintă caracteristica iniţială şi constantă, urmată de apariţia unor manifestări inflamatorii, cum ar fi papulele şi pustulele, iar complicațiile sunt reprezentate de dezvoltarea limfede- mului cronic, îngroşarea pielii afectate şi rinofima $(1,2)$.

Rozaceea este o afecțiune observată frecvent la persoanele cu vârste cuprinse între 30 şi 50 de ani, predominant la caucazieni, cu o rată a prevalenței de $1-10 \%$, cu o predispoziție către sexul feminin, afectarea oculară apare la 58\% dintre cazuri, în timp ce rinofima apare mai ales la bărbații cu vârsta peste 40 de ani $(1,3)$.

În urma unui studiu efectuat în Anglia, s-au identificat 60.042 pacienți cu rozacee, cu o predominanță feminină de $61,5 \%, 80 \%$ având vârsta pes- 
te 30,5 ani; în America, se estimează prezența rozaceei între 10 şi 20 de milioane persoane; în Suedia, raportul femei/bărbați este de 3:1,5; în Estonia s-a găsit o prevalență de $22 \%$ la persoanele cu vârstă peste 30 ani $(4,5)$.

Cauza rozaceei este încă neelucidată, factorii de mediu şi genetici au o influenţă în etiologia rozaceei, iar istoricul familial este prezent în până la $30 \%$ dintre cazuri. Factorii de exacerbare includ consumul de alcool, băuturi calde, consumul de ciocolată, nuci, alimente picante şi brânză, anumite medicamente, expunerea la soare, vreme caldă şi rece, vânt, umiditate, anumite produse de curățare, cosmetice şi stresul emoțional. Menstruația şi sarcina pot, de asemenea, exacerba rozaceea din cauza fluctuațiilor hormonale care cresc vascularitatea cutanată $(2,6,7)$.

Mecanismele patologice ale rozaceei sunt consecințe ale imunității înnăscute, modificărilor vasculare, speciilor reactive de oxigen eliberate de neutrofile, radiaţiilor ultraviolete şi microbilor (8).

Pacienții cu rozacee prezintă o provocare pentru dermatolog, având de obicei o piele sensibilă, au nevoie de control al demodexului facial şi de control al colonizării bacteriene, prezintă instabilitate vasomotorie, necesită camuflarea covoraşelor telangiectatice şi necesită un instructaj amănunţit în ceea ce priveşte îngrijirea cutanată. Dispozitivele farmaceutice disponibile în prezent vizează reducerea inflamaţiei, în principal prin utilizarea antibioticelor topice şi orale. Recent, au apărut formule vasoconstrictoare, dar aceste medicamente au doar un efect temporar şi îmbunătățesc aspectul fără a se adresa cauzei care stă la bază, aceasta fiind încă necunoscută. Produsele cosmetice de curățare, hidratante, produse de protecție solară şi medicamente antiinflamatoare pot fi utilizate ca terapii adjuvante în combinație cu terapiile tradiționale. Aceste produse pot fi utilizate în tratamentul rozaceei pentru a îmbunătăți rezultatele medicamentelor farmaceutice.

\section{CURĂTAREA}

Curăţarea este o componentă importantă a menținerii sănătății pielii şi ajută la pregătirea ei pentru tratamentele locale pe bază de prescripție. Curățarea feței este importantă la pacienții cu rozacee, deoarece rozaceea reprezintă o boală a biofilmului. În ceea ce priveşte curăţarea corectă a feței la pacienții cu rozacee, trebuie avute în vedere îndepărtarea excesului de sebum, rezidurile de mediu, corneocitele descuamate, organismele nedorite, produsele cosmetice şi îngrijirea specială a pielii îmbătrânite, păstrând în acelaşi timp bariera cutanată. Protecția de barieră a pielii este esențială, deoarece pacienții cu rozacee formează un subset de pacienți cu pielea sensibilă, care prezintă efecte adverse atunci când sunt expuşi la iritante uşoare sau la substanțe care produc stimuli senzoriali nocivi (9).

Produsele de curățare sunt eficiente în îndepărtarea lipidelor de pe suprafața pielii, dar agenții activi de suprafață nu pot distinge între sebumul şi lipidele intercelulare. Îndepărtarea profundă a sebumului, care este necesar pentru creşterea bacteriilor şi a fungilor pe piele, poate, de asemenea, să deterioreze lipidele intercelulare, ducând la deteriorări ale barierei, care se manifestă prin roşeață facială, arsuri şi prurit. Selectarea produsului de curățare potrivit este foarte importantă în tratarea rozaceei, acesta trebuie să se potrivească cu necesitățile pacientului de producere şi de curățare a sebumului. Majoritatea pacienților din grupa de vârstă predominantă în rozacee posedă piele mixtă, fiind acceptabilă recomandarea unui produs de curățare pentru pielea grasă în partea centrală a feței şi o substanță de curățat pentru pielea uscată pentru părțile laterale ale feței. Personalizând curăţarea în funcție de fiecare zonă, curățare urmată de clătirea cu apă, se poate contribui la normalizarea biofilmului, menținând în acelaşi timp bariera pielii (10).

Pentru curăţarea pielii, recomandată pacienților cu rozacee dimineaţa şi seara, pentru a minimiza trauma facială, pacientul ar trebui să folosească numai mâinile, fără alte dispozitive. Degetele acoperite cu agentul de curățare pot ajunge în curbele şi pliurile din jurul nasului, unde cresc organismele pityrosporum ce pot duce la suprapunerea dermatitei seboreice cu rozaceea. Degetele sunt, de asemenea, utile pentru curăţarea sprâncenelor şi bărbiei afectate de dermatită seboreică. Apa trebuie să fie călduță pentru a preveni înroşirea feței cauzată de schimbarea rapidă a temperaturii. Apa abundentă ar trebui să fie stropită pe față pentru a îndepărta bine substanța de curățare; dacă nu este complet clătit, agentul de curățare poate provoca iritații. Pielea trebuie uscată uşor cu un prosop moale pentru a reduce la minimum roşeața indusă de frecare $(11,12)$.

TABELUL 1. Curățarea în funcție de tipul de piele

\begin{tabular}{|l|l|l|}
\hline $\begin{array}{l}\text { Tipul de piele } \\
\text { cu rozacee }\end{array}$ & $\begin{array}{l}\text { Tip de } \\
\text { curățare }\end{array}$ & Detalii \\
\hline Piele grasă & Săpun & $\begin{array}{l}\text { Săruri alcaline cu acizi grași } \\
\text { cu lanţ lung cu un pH cuprins } \\
\text { între 9 și 10 }\end{array}$ \\
\hline Piele normală & Syndet & $\begin{array}{l}\text { Detergenţi sinte ci, conţin } \\
\text { mai puţin de 10\% săpun, pH } \\
\text { ajustat de 5,5-7 }\end{array}$ \\
\hline Piele uscată & $\begin{array}{l}\text { Soluţie de } \\
\text { curăţare fără } \\
\text { lipide }\end{array}$ & $\begin{array}{l}\text { Lichide care curăţă fără } \\
\text { grăsimi }\end{array}$ \\
\hline
\end{tabular}




\section{HIDRATAREA FACIALĂ}

Următoarea etapă după curățare este aplicarea unei soluții hidratante, ea poate fi utilă pacienților cu rozacee care au pielea normală sau uscată. Solutiile hidratante sunt importante pentru a oferi un mediu optim pentru repararea barierei. Cremele hidratante imită efectul sebumului la nivelul suprafeței pielii prin împiedicarea evaporării apei din piele în mediul înconjurător, dar nu trebuie să susțină creşterea bacteriilor, de aceea nu se vor utiliza hidratante care conțin uleiuri din materii vegetale sau animale care ar putea stimula creşterea bacteriilor (ex: ulei de nucă de cocos, măsline, cânepă, argan şi floarea-soarelui). Hidratantele pe bază de silicon sunt considerate cele mai bune, deoarece sunt plăcute din punct de vedere estetic, nu fac pielea să se încălzească şi nu susțin creşterea organismelor. Soluţia hidratantă ar trebui să încerce să imite lipidele intercelulare, care sunt compuse din sfingolipide, steroli liberi şi acizi graşi liberi (13).

Soluțiile hidratante sunt folosite pentru vindecarea pielii atunci când bariera acesteia este afectată, prin minimizarea pierderii transepidermale a apei şi prin crearea unui mediu optim pentru controlul rozaceei. Cele 3 categorii de substanțe care pot fi combinate pentru a spori conținutul de apă al pielii sunt ocluzive, umectanți şi hidrocoloizi. Ocluzivele sunt substanțe uleioase care întârzie pierderea apei transepidermice prin plasarea unei pete de ulei pe suprafața pielii, iar umectanții sunt substanțe care atrag apa spre piele - nu din mediul înconjurător, ci mai degrabă din straturile interioare ale pielii. Hidrocoloizii sunt substanţe care acoperă pielea şi astfel întârzie pierderea apei transepidermale (14).

Cele mai bune produse de hidratare pentru a preveni rozaceea combină ingrediente ocluzive şi umectante, de exemplu, un hidratant bine formulat ar putea conține petrolatum, ulei mineral şi dimeticonă ca agenți ocluzivi. Petrolatum este substanța sintetică care seamănă cel mai mult cu lipidele intercelulare, dar o concentrație prea mare va avea ca rezultat un unguent gras şi lipicios. Uleiul mineral nu este la fel de uleios ca petrolatumul, dar este un agent excelent de reparare a barierei cutanate, îmbunătățind în capacitatea de hidratare şi ducând la o îmbunătățire din punct de vedere estetic. Adăugarea de glicerină în formulă va atrage apa din derm, accelerând astfel hidratarea (15).

\section{PROTECTIIA SOLARĂ}

Pacienții cu rozacee necesită protecție solară cu spectru larg, cum ar fi cu un factor de protecție so- lară de minimum $30+$ pentru a obține acoperire împotriva radiațiilor ultraviolete UVB şi UVA. Proteinele solare anorganice, cum ar fi dioxidul de titan şi oxidul de zinc, nu eliberează căldură atunci când sunt în contact cu radiațiile UV, ci mai degrabă reflectă energia. Acest lucru înseamnă că pacienții cu rozacee ar trebui să aleagă creme hidratante cu protecție solară care conţin dimesiconă şi oxid de zinc pentru cele mai bune rezultate $(16,17)$.

\section{COSMETICE PENTRU CAMUFLAJ ÎN ROZACEE}

Următorul pas după curățare şi hidratare în ceea ce priveşte aspectul de piele roşie, caracteristică rozaceei, este reprezentat de cosmeticele colorate, ele sunt utile pentru camuflarea rozaceei în special la pacienții de sex feminin. Produsele cosmetice camuflează roşeața care stă la bază fie prin amestecarea culorilor, fie prin ascunderea pielii subiacente. Arta amestecării culorilor pentru a minimiza roşeața feței utilizează culoarea verde, care este complementară roşului. Se aplică hidratante cu o uşoară nuanță verde după medicația prescrisă. Câteva hidratante comercializate în prezent pentru rozacee conțin o uşoară nuanță verde. Deoarece amestecul de roşu şi verde produce maro, nuanța verde intensă va atenua roşeaţa strălucitoare a obrajilor. O fundație facială trebuie aplicată peste nuanța verde pentru a obține o camuflare completă. Camuflarea poate fi realizată şi cu pudră facială verde. Aceste pulberi conțin un amestec de pigmenți proiectați pentru a atenua zonele roşii ale feței la persoanele care nu doresc să poarte o fundație facială; pudra are o absorbție bună a excesului de sebum (12).

Telangiectazia feței este uneori prea severă pentru a fi acoperită de o fundație tradițională sau pudră; în acest caz, poate fi utilă aplicarea de brimonidină vasoconstrictor (cu prescripție) înainte de aplicarea cosmeticelor. Dacă brimonidina nu este adecvată, se pot utiliza produsele de camuflaj folosite în general după operații. Acestea sunt creme groase cu o concentrație mare de pigment şi substanțe anhidre, care conferă proprietăți impermeabile.

\section{INGREDIENTELE BOTANICE}

Ingredientele antiinflamatoare botanice, care au rolul de a reduce roşeața feței prin întreruperea cascadei inflamatorii, sunt adesea introduse în formulele hidratante pentru rozacee. 
TABELUL 2. Ingredientele botanice şi efectele acestora (12)

\begin{tabular}{|l|l|l|}
\hline Ingredient & Agent activ & Efect \\
\hline Ginkgo biloba & $\begin{array}{l}\text { Terpenoide (ginkgolidă, bilobalidă), flavonoide, } \\
\text { flavonol glicozide }\end{array}$ & $\begin{array}{l}\text { Reduce circulaţia la nivel capilar, reduce inflamaţia prin } \\
\text { efecte an radicali și an lipoperoxidante }\end{array}$ \\
\hline Ceai verde & $\begin{array}{l}\text { Polifenoli, cum ar fi epicatechină, epicatechin-3-galat, } \\
\text { epigallocatechină, epigallocatechin-3-galat }\end{array}$ & $\begin{array}{l}\text { Reduce inflamaţia indusă de ultraviolete B (UVB) prin } \\
\text { funcţionarea ca an oxidant }\end{array}$ \\
\hline Aloe vera & $\begin{array}{l}\text { Aloin, aloe emodin, acid ale nic, colină, salicilat de } \\
\text { colină }\end{array}$ & Derivatul de salicilat inhibă calea ciclooxigenazei \\
\hline Alantoină & Diureida acidului glioxilic & $\begin{array}{l}\text { Îmbunătăţește capacitatea de menţinere a apei din } \\
\text { matricea extracelulară, îmbunătăţind funcţia de barieră }\end{array}$ \\
\hline Spilcuță & Parthenolid, tane n & Inhibă eliberarea de prostaglandine și serotonină \\
\hline Glycyrrhiza inflata & Licochalcona A & $\begin{array}{l}\text { Inhibă eliberarea de kera nocite a prostaglandinelor ca } \\
\text { răspuns la eritemul indus de UVB }\end{array}$ \\
\hline
\end{tabular}

Contrar îngrijirii corespunzătoare şi medicației orale şi/sau topice, rozaceea se poate agrava. O serie de măsuri sunt necesare în aceste situații, cu atât mai mult cu cât agravarea poate surveni din cauza unui produs cosmetic utilizat.

TABELUL 3. Măsuri în cazul agravării rozaceei (18)

\begin{tabular}{|c|}
\hline $\begin{array}{l}\text { În cazurile în care rozaceea se agravează în timpul } \\
\text { tratamentului se vor respecta următoarele: }\end{array}$ \\
\hline $\begin{array}{l}\text { Opriți utilizarea tuturor produselor cosmetice, inclusiv } \\
\text { parfumurile. Se va utiliza numai un produs de curățare fără } \\
\text { lipide și o cremă hidratantă blândă timp de } 2 \text { săptămâni. }\end{array}$ \\
\hline $\begin{array}{l}\text { Opriți tratamentul topic prescris timp de } 2 \text { săptămâni. Evitați } \\
\text { în special medicamentele care conțin retinoizi, peroxid de } \\
\text { benzoil, acid glicolic și propilen glicol. Medicamentele orale } \\
\text { pentru rozacee pot fi continuate. }\end{array}$ \\
\hline Eliminați toate sursele de frecare la nivel facial. \\
\hline $\begin{array}{l}\text { Stopați orice activitate fiziă care implică frecare pielii la nivel } \\
\text { facial, cum ar fi călărie, fotbal și ciclism, pentru care este } \\
\text { necesară o cască cu o curea pentru bărbie. }\end{array}$ \\
\hline $\begin{array}{l}\text { Evaluați pacientul la } 2 \text { săptămâni pentru a stabili dacă au } \\
\text { apărut îmbunătățiri sau dacă există concomitent dermatoză. } \\
\text { Dacă este prezentă o dermatoză subiectivă, cum ar fi } \\
\text { dermatită seboreică, psoriazis, eczemă, dermatită atopică } \\
\text { sau dermatită periorală, tratați corespunzător până la } 2 \\
\text { săptămâni după ce toate semnele vizibile ale bolii de piele nou } \\
\text { diagnosticate au dispărut. }\end{array}$ \\
\hline $\begin{array}{l}\text { Efectuați un test cutanat pentru a identifica alergenii cu } \\
\text { relevanță pentru aplicarea facială. Determinați care dintre } \\
\text { acești alergeni sunt relevanți din punct de vedere clinic și faceți } \\
\text { recomandări pentru a-i evita. }\end{array}$ \\
\hline $\begin{array}{l}\text { Evaluați starea psihică a pacientului, în special semnele de } \\
\text { depresie, simptome de menopauză sau boli psihiatrice. }\end{array}$ \\
\hline
\end{tabular}
depresie, simptome de menopauză sau boli psihiatrice.
Permiteți pacientului să adauge câte un produs cosmetic în următoarea ordine: ruj, pudră, fard de obraz.

Utilizați-testați toate produsele cosmetice necesare

pacientului, prin aplicare pe timp de noapte, pe o suprafață de $2 \mathrm{~cm}$ laterală a ochiului, timp de cel puțin 5 nopți consecutive. Cosmeticele se vor testa în următoarea ordine: rimel, creion pentru ochi, creion pentru sprâncene, fard de obraz, fond de ten, pudră și orice alt produs cosmetic colorat.

În cele din urmă, folosiți-testați toate medicamentele utilizate pentru rozacee, aplicându-le noaptea pe o zonă de $2 \mathrm{~cm}$ laterală a ochiului, timp de 5 nopți consecutive.

Analizați toate datele și prezentați pacientului o listă de medicamente, produse de îngrijire a pielii și produse cosmetice adecvate pentru utilizare.

\section{CONCLUZII}

Pe lângă medicaţia topică şi/sau orală utilizată în rozacee, este foarte importantă instruirea pacientului în ceea ce priveşte îngrijirea zilnică a feței cu produse complementare. De multe ori, îngrijirea corespunzătoare poate preveni apariția puseelor sau limitarea acestora. Tratamentul medicamentos, ajutat de produsele complementare, corect utilizate, va avea un efect sporit. Sunt foarte importante înțelegerea şi respectarea de către pacientul cu rozacee a igienei şi a îngrijirii tenului pe termen lung.

\section{Mențiune}

Toți autorii au contribuție egală la realizarea acestui articol.

Conflict of interest: none declared Financial support: none declared

\section{BIBLIOGRAFIE}

1. SA Buechner. Rosacea: An update. Dermatology, 210 (2005), pp. 100-108

2. GH Crawford, MT Pelle, WD James. Rosacea: etiology, pathogenesis, and subtype classification. J Am Acad Dermatol, 51 (2004), pp 327-341

3. D Fuller, S Martin. Rosacea. J Midwifery Womens Health, 57 (2012), pp 403-409

4. J Spoendlin, JJ Voegel, SS Jick, CR Meier. A study on the epidemiology of rosacea in the UK. Br J Dermatol, 167 (2012), pp 598-605
5. K Abram, H Silm, M Oona. Prevalence of rosacea in an Estonian working population using a standard classification. Acta Derm Venereol, 90 (2010), pp 269-273

6. T Erdem, N Metin. Rosacea. Dermatose, 3 (2012), pp 19-26

7. JQ Del Rosso. Advances in understanding and managing rosacea, part 1: Connecting the dots between pathophysiological mechanisms and common clinical features of rosacea with emphasis on vascular changes and facial erythema. J Clin Aesthet Dermatol, 5 (2012), pp 16-25

8. BE Elewski, Z Draelos, B Dreno, T Jansen, A Layton, M Picardo. 
Rosacea-global diversity and optimized outcome: proposed international consensus from the Rosacea International Expert Group. J Eur Acad Dermatol Venereol, 25 (2011), pp 188-200

9. DA Basketter, HA Griffiths. A study of the relationship between susceptibility to skin stinging and skin irritation. Contact Dermatitis, 29 (1993), pp 185-188

10. Jessica Krisiak, Stacy Hawkins, Kevin Hermanson. Compatibility and tolerability of a new nonfoaming facial cleanser for subjects with rosacea. Journal of the American Academy of Dermatology, Volume 79, Issue 3, Supplement 1, 2018, Page AB84

11. Matthew H Meckfessel, Sandrine Teissedre, Nadege Lachmann. An effective yet gentle foaming facial cleanser specifically designed for redness-prone skin. Journal of the American Academy of Dermatology, Volume: 79, Issue: 3, 2018, Page: AB37

12. Zoe Diana Draelos. Cosmeceuticals for rosacea. Clinics in Dermatology, Volume 35, Issue 2, 2017, Pages 213-217,

13. Matthew Meckfessel, Sandrine Teissedre, Nadege Lachmann, Francine Santoro. Performance of a facial night moisturizer designed for redness-prone skin. Journal of the American Academy of Dermatology, Volume: 79, Issue: 3, 2018, Page: AB219
14. Schaller M, Schöfer H, Homey B, Hofmann M, Gieler U, Lehmann P, Luger TA, Ruzicka T, Steinhoff M. Rosacea Management: Update on general measures and topical treatment options. Journal der Deutschen Dermatologischen Gesellschaft, 2016, Volume 14, Issue S6, Pag 17-26

15. Del Rosso JQ. Adjunctive skin care in the management of rosacea: Cleansers, moisturizers, and photoprotectants. Cutis 2005 Mar;75(3 Suppl):17-21

16. Grivet-Seyve M, Santoro F, Lachmann N. Evaluation of a novel very high sun-protection-factor moisturizer in adults with rosacea-prone sensitive skin. Clin Cosmet Investig Dermatol 2017 Jun 10;10:211-219

17. JQ Del Rosso, D Thiboutot, R Gallo et al. Consensus recommendations from the American Acne \& Rosacea Society on the management of rosacea, part 1: A status report on the disease state, general measures, and adjunctive skin care. Cutis, 92 (2013), pp 234-240

18. ZD Draelos. Sensitive skin: Perceptions, evaluation, and treatment. Am J Contact Dermat, 8 (1997), pp 67-78 